\title{
History Education for Arab Palestinian Schools in Israel
}

\author{
Hatim Mahamid ${ }^{1}$ \\ ${ }^{1}$ College of Sakhnin for Teachers' Education, The Open University of Israel, Israel \\ Correspondence: Hatim Mahamid, College of Sakhnin for Teachers' Education, The Open University of Israel, \\ Israel.
}

Received: December 9, 2017

Accepted: December 12, 2017 Online Published: December 14, 2017

doi:10.20849/jed.v1i1.249

URL: https://doi.org/10.20849/jed.v1i1.249

\begin{abstract}
Since 1948, the Educational system for Palestinian Arabs in Israel was affected by political and ideological considerations of the Jewish state policy. Nurit Peled-Elhanan (2012) argues that the textbooks used in the school system in Israel are laced with a pro-Israel ideology and that they play a part in priming Israeli children for military service. She analyzes the presentation of images, maps, layouts and use of language in History, Geography and Civic Studies textbooks, and reveals how the books might be seen to marginalize Palestinians, legitimize Israeli military action and reinforce Jewish-Israeli territorial identity. Up until 1987 the Department for Arab Education was headed by a Jewish-Israeli director who was appointed by the Ministry of Education and involved in policy making for ensuring control over the Palestinians. Since then Palestinians have been appointed to lead the Department but they have been lacked of power or decision making, which remained under the direct control of the Ministry of Education. Thus the Department for Arab Education has no autonomous decision and authorities, but only meant to supervise the education of Palestinian Arabs and answer to Jewish-Israelis who continue to be in charge. Since the first years Israeli politicians saw in the state education system, an instrument to realize Zionist political objectives, and on the other hand the educational system was used to ensure weakening of Arab and Palestinian identity in the country.
\end{abstract}

Keywords: history education, Palestinian schools, Israeli policy and curricula

\section{Introduction}

Since 1948, history curricula for Arab schools in Israel had passed in three main stages: a. 1949-1974, which was characterized of centralization and closure affected by a strict control from the high policy of the Jewish State. b. 1975-1990: Redefinition of the objectives of the educational curricula (al-Haj, 1994). c. Since the 1990s, new revisions had been done for planning modern and revised curricula for history education in Palestinian Arab schools. The new curriculum was authorized in 1999, but the final approval was in 2005 (History Curriculum for High Arab Schools, 1999, 2007).

Although the Arab school system has a separate curriculum, it is supervised and continues to be formulated by the Ministry of Education governed by a set of political and ideological criteria. This study will trace the attempts for changes in history curricula dedicated for Palestinian pupils in Israel, stressing on curricula of Palestinian high schools. It also tries to examine whether those curricula fulfill the desire and requirements of the Palestinian education. So some questions can be asked: To what extend was history education for Arab High schools changed? What factors had affected on the change process? Thus the aim of this study is to focus on the formation of history curricula and education for Arab high schools in Israel, and follow the changes since 1948 and on, in light of the historical and political circumstances.

\section{Objectives of History Education}

\subsection{Initial Educational Goals and Policy}

During the first twenty years of the State of Israel Jewish, national objectives were viewed as being of the highest interest in the educational endeavor. After the establishment of the State of Israel in 1948, educational trends were unified under the supervision of the Ministry of Education in 1953. Daniel Bar-Tal (2001) stated that the Ministry of Education had the authority to approve the use of school textbooks on the basis of curricula developed by the ministry which indicate the didactic, scholastic and societal objectives that should be achieved. In 1953 the Minister of Education then, Prof. Ben-Zion Dinur stated the goals of education on the basis of national and societal ones. 
In 1953 Israel passed the Public Education Law with the aim to centralize the education system after it had been initially constituted in 1949. The first goal stated in that law that the educational system seeks to "raise youth on the values of Israeli culture, and love of the (Jewish) nation and people of Israel" (Mar'i, 1978). This goal continued to formulate the main objective in history education for Jewish and Arab learners. Until the 1980s and 1990s no positive goals have been formulated for the education of Palestinians based on the values of Arab, Muslim, Christian culture and the Palestinian nation. Abu Saad stated that even there had been a revision done in the official educational law in Israel in 2000, the general objectives remained and continued to stress on the values, history and culture that serve the Jewish interests, while at the same time values, Palestinian culture and history are neglected (Abu Saad, 2006a; Abu Sa'ad, 2011, pp. 104-107).

\subsection{The Beginning of History Curriculum}

The first core curriculum for teaching history in Israel published in 1954 presented Jewish-Israeli ethnocentrism as a broad normative dimension of the struggle for national liberation. This curriculum placed the teaching of history fully in the service of the Jewish-Israeli national enterprise and the construction of the mobilized society. The main themes of the history curriculum were the effort to form a "consciousness of place" linked to the old-new homeland related to the Jewish people. Raz-Krakotzkin argues in a critical essay on the History and Biblical Studies curricula that the land of Israel was shaped by a mythical representation that cast it not as a historical-territorial entity but as an image based on the Bible, and the so-called "yearning of generations" (Raz-Krakotzkin, 1997, pp. 19-21). Consequently the teaching of Palestine's history in Israeli schools, both Jewish and Arab, is based on the Zionist narrative which holds that Jews are one people that formed their identity in the land of Israel (Palestine) more than one thousand years ago, and returned to it to form that identity again (Barghouthi, 2009; Yogev, 2010).

Yoav Gilber stated eight objectives included in the curriculum of 1954. By examining those objectives one can conclude that the main aims were to give knowledge to the students about the "glorious past of Jewish people" and "Jewish culture" to enhance the sense of worship and love to famous and important Jewish acquisitions, leaders and characters, to give pupils acknowledgement and respect to the leaders who acted for establishing the state of Israel, to instill in them loyalty and love to the country (Israel) and the strong desire to do for it (Gilber, 2009, pp. 18-19).

The first history curriculum for Jewish public and religious elementary schools published in 1954, was translated into Arabic with some adjustments, and Palestinian students were expected to learn the same narrative as in the Jewish schools. Arab and Jewish teachers were subsequently charged with the task of preparing textbooks according to that curriculum. Barghouthi in his essay tried to investigate how Zionist history has been presented to Palestinian students in history textbooks up until 1975 . He stated there and concluded that early history textbooks for Palestinian pupils depended on the perspective of the Jewish "people of Israel" based on the Bible. History at that time was taught with ideas introduced in elementary school (fifth through eighth grade), revisited and expanded upon in High School (ninth through twelfth grade) (Barghouthi, 2009).

Through their studies Arab and Jewish researchers have criticized the curricula for Arabs and stated that Arab students are required to spend many class hours in the study of Jewish culture, history and the Hebrew language while they spend less on Arabic literature and history. Thus they are required to develop identification with Jewish values and further Zionist aspirations at the expense of the development of their own national awareness and sense of belonging to their own people. The Arab national identity is not emphasized and the Palestinian identity goes completely unrecognized and neglected. Furthermore, the basic goal of Jewish studies in Arab education is not the development of cultural competence as a bridge to Jewish Israeli society but is rather to make Arabs understand and sympathize with Jewish and Zionist causes and cover up their own national identity in Israel (Mar'i, 1978; Al-Haj, 1995; Abu Saad, 2006a, pp. 715-716).

School textbooks remain agents of mass enlightenment and social control in Israel, since teachers are obliged to base their instruction upon Ministry of Education-approved textbooks, and teachers rely on them to organize their lessons in most school systems. Daniel Bar-Tal states in his study that "Textbooks, for better or for worse, dominate what students learn. They set the curriculum, and often the facts learned, in most subjects. For many students, textbooks are their first and sometimes only early exposure to books and to reading. The public regards textbooks as authoritative, accurate and necessary and teachers rely on them to organize lessons and structure subject matters" (Bar-Tal, 2001). Abu Saad also stated that the public tends to regard textbooks as essential, authoritative, and accurate knowledge. Those textbooks dominate what students learn at school, and determine the curriculum (Abu Saad, 2006a, pp. 712-713).

Esther Yogev argues and criticizes those objectives of history education, in general in Israel in the way a 
sequence was constructed in which events and figures from the history of the Biblical Israel were identified with and linked to the Zionist enterprise as a national-cultural mission. She emphasizes that "The purpose of teaching history in a life-embracing democratic society is not to instill a certain opinion or rigid ideological stance. On the contrary, teaching history is supposed to epitomize education for democratic thinking - that is, education designed to foster critical abilities and complex insights as a basis for making intelligent, independent choices between alternatives. Only this kind of education will strengthen Israeli society as a community capable of accepting the shadows of the past and the uneasiness of the present, thereby striving to improve its future maturely and rationally..." (Yogev, 2010).

\subsection{Developed History Curriculum and Arab-Palestinian Values}

The new curriculum of history for Arab Secondary Schools which had been authorized in 1999 revised again in 2005 and published in 2007, stated in its goals some new important points of educational goals for enhancing the sense of Arab-Palestinian values, in addition to the "loyalty for the State of Israel" (History Curriculum for High Arab Schools, 1999, 2007):

- Deepening the sense of Arab students for belonging to Palestinian People and to the Arab nation in general and its culture, and the loyalty to the State of Israel and its people.

- To know the history of Palestine, the history of the Arab Palestinians and the status of Palestine in the Arab consciousness.

- To know the history of the Arab nation and its culture.

- To know the history of Islam: religion and its expansion.

- To know the history of the Jewish People within the country and in the diaspora, besides knowing the place of Palestine (Land of Israel) in the history and consciousness of the Jewish People.

Nevertheless, the question remains as it is: Did the new curriculum cover the declared objectives on behalf the Palestinian and Arab History? By comparing between the objectives of history education in both Arab and Jewish schools, differences can be pointed out clearly; in Jewish schools the stress is on national objectives in teaching history, while in Arab schools this goal is neglected. Instead in Arab educational system the emphasis is on enhancing the value of co-existence between Arabs and Jews, with supremacy for Jews. The Arab students should know the function that Arab and Jews fulfilled through history and be aware to the shared fate of the two peoples. On the other hand, values of such co-existence are not bestowed to Jewish students (al-Haj, 1994; al-Haj, 1995; Abu Saad, 2011, pp. 104-105).

\section{History Curricula for Arab High Schools: Changes and Developments}

History-teaching in Israel has changed over the years affected by sensitive subject matters, and the political and social contexts have both reflected and shaped the history curriculum. Esther Yogev stated that the foregoing review of events nowadays indicate that history-teaching in Israel has made some progress. However it is patently still affected by the conflict between the dictates of heritage and critical historical literacy between the establishment's insistence on inculcating a uniform hegemonic narrative and the effort to expand the role of critical analysis in history study - and thereby also to reduce the gap between the curriculum and the continuously changing story of Israeli life (Yogev, 2010).

\subsection{The Effect of Military Policy on History Curricula -1948-1966}

The first years of the new state of Israel were characterized by a military policy against the remaining Palestinian Arabs and a strict control in all aspects of life. In early 1949 an appointed committee for Arab education had begun in arranging and planning educational curricula for Palestinian Arab schools in Israel. Another sub-committee had been established to deal with the objectives and textbooks needed for those schools. That committee was authorized to illegitimate any textbook seems to be impair from the point of political and educational views or other factors. Likewise, the committee was given the authority to find the resources for production new appropriate textbooks instead. At the same time the Arab teachers had received strict instructions to leave out the parts related to Arab nationalism in history and geography textbooks. Thus, this important aspect of education had been under control of the high policy of the Jewish state (al-Haj, 1994, 1995; Kabha, 2009, pp. 71-76).

The law of state education led to the formation of the first central and general plan and curricula of history education in Israel, aimed to be obligating to the whole students in the country, Jewish as Palestinians. The new curricula had been published in 1954, intending to exchange the old one related to the period of the British Mandate. Thus the first core curriculum for teaching history in Israel published in 1954, presented Jewish-Israeli 
ethnocentrism as a broad normative dimension of the just struggle for national liberation. This curriculum placed the teaching of history fully in the service of the national Jewish enterprise and the construction of the mobilized society. This curriculum included discussion of 53 secondary topics relating to the period preceding the establishment of the state: 14 of them in general history and 39 in Jewish history. Most of them cast Diaspora life in a negative light, and presented the Zionist solution as a unique historic imperative (Naveh \& Yogev, 2002, pp. 38-39).

Ruth Firer claims that in the first two decades of the state, a comprehensive and institutionalized de-legitimization of the Israeli Arabs was obvious in the textbooks. The education system in general and the history curriculum in particular completed the elevation of the army by making a distinction between the "good" Israeli (the Jews) and the "bad" Arab. This Jewish-Arab divide was reinforced in the school system of the 1950s and 1960s, first of all by the exclusion of Israeli Arabs from the civil consensus. Moreover, history curricula and textbooks made no reference to the Jewish-Arab conflict as a complex, multisided issue with universal implications (Firer, 2008, pp. 199-200).

As mentioned above, history education in Israel in the 1950s and 1960s served to achieve the political and ideological perspectives of the Jewish majority. The distinction between heritage and critical analysis in history teaching began to form in the 1970s. By the 1990s there was already a notable gap between the heritage-inculcating establishment position and the professionals in the field and in the academic world, who wanted to expand the role of criticism. It was this gap that, towards the end of the 1990s, gave rise to the turbulent public controversy (Yogev, 2010).

\subsubsection{The Image of Arab-Palestinians in Hebrew School Textbooks}

The curriculum in Jewish Israeli schools has been instrumental in explicitly and implicitly constructing racist and threatening stereotypes and a one-sided historical narrative that left a strong and deep effect on Jewish students' views and has provided the basis for maintaining a deeply divided society. A study about "The Arab image in Hebrew school textbooks" done by Daniel Bar-Tal and other researchers (Bar-Tal, 2001; Bar-Tal \& Zoltak, 1989) found that over the years generations of Israeli Jews were taught a negative and often delegitimizing view of Arabs. Referring to Israeli texts of the 80s and 90s, Bar-Tal (2001) reports that geography and history textbooks for Jewish Schools in general and in junior high schools, in particular gave a negative picture of Arabs, primitive, dirty, aggressive and hostile to Jews. The same results Abu Saad has found that the majority of those books cover the Arab-Jewish conflict, stereotype the Arabs negatively, and they are presented uncompromising (Abu Saad, 2006a, pp. 712-715; Abu Saad, 2011, pp. 136-159).

A comparable study of the conflict's portrayal in textbooks, the Israeli historian Elie Podeh found that the books used in those years presented a negative stereotype of the Arab too. The cycles of violence between Jews and Arabs in the Mandate period were described as "disturbances" and "pogroms" perpetrated against Jews by "wily", "cheating" and uncivilized Arab "agitators". Podeh further notes that textbooks did not mention the problem of Palestinian refugees, or that Israel had played an indirect part in creating that problem. Thus the word "expulsion" does not appear in these books. So according to those textbooks the Arabs of Palestine simply "ran away", "left", "fled", "evacuated" or "abandoned" their homes and they fled in fear of the war, running for their lives with the encouragement of the Palestinian Arab leadership (Podeh, 2002, pp. 166-177). In a new study of Nurit Peled-Elhanan, she also concluded that hundreds of books, she did not find one photograph that depicted an Arab as a "normal person". The most important finding in the books she studied-all authorised by the ministry of education - concerned the historical narrative of events in 1948, the year in which Israel fought a war to establish itself as an independent state, and hundreds of thousands of Palestinians fled the ensuing conflict (Peled-Elhanan, 2012).

\subsection{The Effect of the Six Day War (June 1967) on Changing of Textbooks and Curricula}

The 1960s witnessed the first cracks in the monolithic image of a mobilized Israeli society. The Six Day War (June 1967) had marked the beginning of a maturation period in the education system - a period that continued until the mid-1980s and was characterized by a growing awareness of the issue of the Israeli-Arab conflict. Direct contact with Arab residents of the West Bank and Gaza, as well as the publication of new studies on the Arab and Palestinian worlds, created a need for deeper knowledge of this subject. The new political situation brought about a change in the description of Arabs in textbooks: expression of the de-legitimization diminished but the negative and familiar stereotypes were preserved (Yogev, 2010).

Esther Yogev added and emphasized that the effect of the 1973 War deepened the schisms in the Israeli collective and intensified the need to expand the new thinking to the education system. The new history curriculum for Jewish pupils introduced in 1975 was defined as an act of shaping derived from the knowledge structure of the 
discipline and the intellectual and psychological needs of the pupils. The curriculum emphasized thinking, discipline and values, and featured cooperation between the Ministry of Education and the academic thoughts. The new textbooks written for the 1975 curriculum included certain changes in the presentation of conventional Zionist "truths": cracks appeared in the myth that Palestine had been an empty wasteland when Zionist immigration began. Despite these changes, the new books were noticeably similar to the first-generation textbooks. Arab history and culture, and the treatment of the Palestinian refugee issue, were still not studied for their own sake, but examined through the Zionist perspective of the Jewish-Arab conflict (Yogev, 2010).

Regarding changes in history education for Arab pupils, Sa'id Barghouthi who began his work as school inspector and coordinator for the history team in the Arab schools in 1975, claimed in his essay that during his new position he began to set out to change the situation of prejudice (Barghouthi, 2009). Otherwise Yogev stated from her point of view that the statehood generation of Israeli Arabs which had undergone a political radicalization would no longer settle as the previous generation had, for being a "tolerated" group dependent on the charity of the regime. Through the Arab political parties whose representation in the Israeli Parliament (Knesset) had grown significantly more numerous, Arab Israelis' demands for equal rights and recognition of their unique identity gained strength (Yogev, 2010).

According to Barghouthi's allegation he stressed that the first success came in 1976 when a new curriculum was issued for elementary and middle schools. He added that the new curriculum differed from its predecessor in inserting the name "Palestine" into the curriculum for the first time instead of "The Land of Israel". Places were named using their original Arabic names rather than the Hebraized names of the older curriculum; Moreover, the emphasis on the Biblical narrative was reduced; Emphasis on the Zionist narrative of the history of Palestine was reduced too, and an Arab-Palestinian historical narrative was introduced. Thus, in other words, the focus of the curriculum was reformed from the Zionist historical narrative of Israel towards a history of Palestine (Barghouthi, 2009).

\subsection{Curriculum Reforms in Light of Political Changes in the 1990s}

It is noticeable that under the effect of different changes and permutation in the Israeli society of the generation after 1973 war (October 6th/Ramadan 10th), educational state system has changed too in shape and curricula. Curricula of history education regarding the Israeli and Zionist history has changed and updated accordingly. Gilber (2009) stated other two more factors have affected on this change: the first one connected to the political change in Israel in 1992 when a new government headed by Yitzhaq Rabin was formed with coalition and support of the left parties and movements. The second factor can be related to the peace atmosphere spread in the 1990s, especially after Oslo peace process in 1993. It is important to mention that through the 1990s, three ministers from the left parties had affected and acted for the change in forming new curricula in educational system. Those ministers served and managed Ministry of Education: Shulamit Aloni (1992-1993), Amnon Rubinstein (1993-1996) and Yossi Sarid (1999-2000).

In the education system of the 1990s for the Jewish schools, there was already a clear distinction between two different educational-ideological trends: the state-secular and the state-religious. The dialectic of these different trends was also expressed in the field of history-teaching in Israel. In 1991 a Governmental Committee for History Curriculum Reform was established, chaired by Professor Moshe Zimmermann of the Hebrew University. Its task was to propose an alternative core curriculum. The "Zimmermann curriculum" which was implemented as a transitional curriculum beginning in 1995, legitimized the expansion of critical approaches in history teaching, a development that had been sought by academics and educators in the field (Mathias, 2005; Gilber, 2009).

\subsubsection{Openness, Pluralism and Self-Criticism in Jewish Curricula with Negative Images}

Elie Podeh (2002, pp. 149-150) concluded in his study that the curriculum for Jewish high schools greatly reduced the ethnocentricity of history instruction and provided wider expression for cultural pluralism. Some of the history textbooks which were published following the work of the committee and in the spirit of the new curriculum present the Jewish-Arab conflict in a more balanced way, and one can sense a new way of thinking which enables greater openness, pluralism and self-criticism, but the books are still full of negative and stereotypical Arabs.

In parallel to those developments in the Jewish Curricula, there had been changes and permutations in history curriculum for Palestinian Arab high schools in Israel. Majid al-Haj in his study and before dealing with the new curriculum recommended to include the topic of modern history of Palestine as an obligatory unit in the history curricula for Arab high school students, and to include more significant parts about the Jewish-Palestinian conflict in order to make balance between the two narratives, of Jewish and of Palestinian one history (al-Haj, 
1994).

\subsubsection{Updated History Curricula for Arab Education in 1999 Without Implementation}

The new and updated history curriculum volume was published in 1999 as an experimental version for Arab schools. This curriculum was considered the most updated one among other educational curricula for Arab education. By examining the details of that version, one can conclude that it is a rewriting of the previous educational curriculum of 1982 with some important changes in objectives. But the noticeable difference was in the component members of the two committees that worked on the curricula: The first committee of the 1980s headed by prof. Yehushua Praver included eight members, half of them were Jewish experts, while the second committee of the 1990s was headed by an Arab professor, Butrus abu Manneh of University of Haifa, and included only one Jewish member (prof. Ilan Pappé) among the others (History Curriculum for High Arab Schools, 1999; Barak, 2004; Barghouthi, 2009).

A significant change of the new curriculum was the statement dealt with the educational objectives. For the first time it contains one of the main and important objectives "... to deepen the sense of belonging of the Arab student in Israel to the Arab Palestinian People, to the whole Arab nation and culture and to the State of Israel and its citizens..." (History Curriculum for High Arab Schools, 1999, pp. 8-9; 2007, pp. 11-12), and not as in previous curricula that stated the belonging to Arab nation in general and the loyalty to the State of Israel, without mentioning the Palestinian people (Barak, 2004).

Despite the updated curriculum of 1999 was accepted by the responsible educational secretary, but it had been revised again, approved in 2005 and published in 2007. The revised version was a shortened copy of the 1999 curriculum, after recommendation of the head inspector of Arab Education, Abdalla Khatib, because of several claims mentioned in the introduction of the revised edition (History Curriculum for High Arab Schools, 2007, p. 5), for instance:

- The 1999 curriculum was detailed more than the two educational units required for the matriculation exams (bagrut) at final stages of secondary education.

- To match the material with the general objectives of the curriculum, and fit it with the hours dedicated to history education (2 hours a week).

Before approving the 1999 history curriculum the Arab student had to get to final exam in two units of history: the first included the history of Arabs and Islam, and the second was about the history of the modern Middle East including the Jewish history in the 20th century and the history of the 20th century in general. In this material there was minimal section taught about the Arab Palestinian society. Otherwise, the new history curriculum for Arab schools published in 1999 included for the first time, a comprehensive chapter about the history of Palestine and Palestinians until 1948 including the Palestinian refugee question (History Curriculum for High Arab Schools, 1999, pp. 28-33).

But surprisingly enough, the chapters related to the Palestinian question included in the new curriculum were not achieved in schools. Omer Barak, in his essay titled "The Palestinian Chapters disappear in the way to Classes", argues why the authorities did not achieve the new curriculum completely as stated in its details. Barak had different answers and analysis and concluded that the high ranking people in charge in the Ministry of Education did not take responsibility on their part of inaccuracy. They claimed who he is to blame was the inspector Sa'id Barghouthi who served a school inspector and history curriculum team coordinator for Arab schools from 1975 until 2004. From the other point of view Barghouthi himself claimed that there was no an available textbook to use for the required material of those subjects (Barak, May 23, 2004).

Regarding the lack of textbooks for Arab schools to fulfill the new curriculum of 1999, Barghouthi explained from his point of view saying "As for high school, I oversaw the preparation of a new curriculum in 1999, which was only approved by the Education Ministry after a two-year long battle. This curriculum included an entire unit called 'Modern Arab-Palestinian Society'. It covers the Palestinian presence on the land until 1948. In the unit on 'The War of 1948', we prepared a chapter titled 'The Origin of the Refugee Problem (Expulsion? Escape?)'. By the time I stopped working with the Ministry of Education in 2004, a version of the textbook that included this chapter had not yet been published. The Arab-Palestinian narrative did however appear in a general, brief form in the three sections of textbooks over which I oversaw preparation. One chapter ends with the sentence "many Palestinians whose cities and villages were occupied were forced to leave their homes and became refugees, because of the dangers of war and its destruction, and because of a number of massacres that were perpetrated against them, such as the Massacre of Deir Yassin in April 1948" (Barghouthi, 2009). 


\subsubsection{Revised History Curricula with Regressive Version}

The new Arab high school curriculum issued in 2007 was followed in 2008 by a new curriculum for elementary and middle school levels, replacing both the 1976 and 1999 curricula. But strangely enough, by examining these new curricula one can obviously notice that the new curriculum for elementary school completely erased modern Palestinian history. Also another omission can be noticed in the curriculum of 2007 related to the chapter called "The History of Arab-Palestinian Society in the Modern Era" for high Arab schools' students, although the objectives remained the same (History Curriculum for High Arab Schools, 2007; Barghouthi, 2009).

Abu Saad emphasizes that despite the changes and attempts to improve the curricula for the Arab schools in Israel, they are still not enough to achieve the educational purposes and desire of Palestinian Arab students (Abu Saad, 2011, pp. 116-122). As it seems, approving the new history curriculum for Arab schools in 1999 with its new objectives did not satisfy the desire of the new Minister of Education then, Limor Livnat (Likkud Party) who was in charge from 2001 till 2006. She acted "... to see every pupil in Israel getting and learning the knowledge and values of Jews and Zionism..." Livnat attended to achieve this goal by a teaching plan of "100 Basic Concepts" curriculum unit that was introduced in the 2004/05 school year. Abu Saad stated in his conclusions about this Israeli educational policy that "A program such as the ' 100 Basic Concepts' demonstrates how the educational aims and goals that were established in the 1953 Law of State Education have continually been renewed and reaffirmed, keeping Palestinian Arabs from being fully present in their own education and basically absent from Jewish education" (Abu Saad, 2006a, pp. 710-711; Abu Saad, 2011, pp. 127-135; Abu Saad \& Mahamid, 2014) (Note 1).

When the Education Ministry was run by Yuli Tamir of the Labour party in 2007, openness and some easiness were adopted towards Arab Palestinian education, but not so long. The term "Nakba" (the Palestinian disaster of 1948), for example, was introduced in books for use in Arab schools. But this term had been removed again from Israeli Arab textbooks through an order by the Israeli authorities. The Israeli Prime Minister Benjamin Natanyahu justified the ban by claiming that using this term was "propaganda against Israel". So it is not strange to hear the response of the recent Israeli Minister of Education Gideon Saar commenting on this case saying that Israel's Ministry of Education will never permit the instruction of anything related to the Palestinian narrative in Israeli schools since “... Israeli Independence shall not be treated like the Holocaust..." (Zonszein, May 25, 2011).

Thus instead of concentration on teaching Palestinian and Arab History as the main chapters in the Arab schools, the Israeli authorities continue in the control policy in this important aspect of education (Al-Haj, 1995; Abu Saad, 2006a; Abu Saad, 2006b; Abu Saad, 2008; Abu Saad, 2011. pp. 104-135). Ultimately and for the first time the Israeli authority tries to include teaching about Holocaust in the Palestinian Arab High schools and be included in the history final exam (bagrut) with a remarkable degree in Summer 2011. An order issued from the General Manager of Education Ministry has sent to Arab Schools to inform them about the new intention of the Ministry that the central chapter of the Bagrut Exam will concentrate on three subjects: firstly, the history of the 20th century, secondly, history of the Israeli nation in the modern period, thirdly, the Holocaust of the Jewish people between 1933- 1945 (Zemer-Pronfman, April 26, 2011).

Problems in Arab Education System in Israel are existed not only in contents of the curricula or execution and lack of suitable textbooks, but also in the many mistakes that Arabic textbooks of different subjects include. According to a report by the Arab Cultural Association, based on a comprehensive study of the language and contents in third grade through ninth grade textbooks, it emerges that there are at least 16,255 mistakes. In three geography and history books, for example, there are 3,939 mistakes. Hundreds of mistakes were also found in textbooks for the study of the Arabic language and Math. George Mansour who examined the history textbooks found that the books ignore the presence of the Arab-Palestinian people in Israel, and the stress is on the Promised Land of the Jewish people: "There is a process of de-Palestinization, instilling of the Zionist narrative and minimizing of Arab culture" (Khoury, May 9, 2011).

\section{Criticism and Controversies Related to History Education in Israel}

During the last four decades several educational experts and history researchers have severely criticized the educational system, because of its instruction on the "state educational law", in which it tried to define targets and goals of the education and direct it to definite objectives. For instance, prof. Tzvi Lam argued that no democratic regime should state educational targets by constitutions and laws, but it is better to give freedom to teachers in expressing their belief and ideas and decide the way to teach. On the other hand Moshe Zimmermann had arrived to conclusions that indicated the decline of the Zionist policy and ideology (Gilber, 2009). Moreover Baruch Kimmerling, a sociologist in the Hebrew University, claims in his study that the ideology of Israeli 
policy had arrived to breakup and decline and failed to unite the different fractions of the societies in Israel among them the Arab community (Kimmerling, 2001).

Esther Yogev (2010) tried to show that history-teaching in Israel is still a bone of contention. She argued that the more history teaching in Israel succeeds in freeing itself of the victimized, stereotypical and defensive perception that attended it from its beginnings there is a better chance of cultivating peace education in young people. At the end of the 1980s the controversial wars and the ideological divisions between the left and the right widened the cracks in the ethos of obligation and commitment. This ethos was superseded by the statehood generation's disappointment over their failure to create a safe and secure environment for their children (Yogev, 2010).

On the other hand those controversies among some Jewish thinkers encouraged high ranking educated personages of different fields among the Arab Palestinian community in Israel to take actions. Since the 1980s they began to present demands and form organizations demanding for taking part of educational decisions. In 1984 a committee called "A follow-up Committee on Arab Education-Israel" (Lajnat Mutaba'at Qadaya al-Ta'lim al-'Arabi), has been initiated and formed among the Arab Palestinian community in Israel. Its function is to follow and take care of all topics related to Arab Palestinians' education and culture. The committee included some high ranking Arab personages among educated Arabs, politicians and public leaders and activists. The main goal of this committee is to act for developing the Arab education with all its aspects, to enhance the knowledge and awareness among Arab community to take their responsibilities in educational and cultural activities, for changing and improving the situations of the Arab education to the best, with its objectives, construct, contents and curricula, materially and functionally, in order to achieve essential equality (The Arab Educational Council, January 1, 2010).

Moreover, until recent time, it is strangely to notice that the Israeli authorities continue to behave differently with the Arab Palestinian society as separated communities: Arab Muslims, Arab Bedouins, Arab Christians, and Arab Druze. That means the official authorities practiced the policy of "separate and govern" towards the Arab Palestinians. The Arab Druze Community for instance is treated differently for their sake, even in the educational system.

After 1975 the educational affairs of the Druze were separated from the Arab educational management, objectives and heritage. Lessons of the Druze Heritage and culture formed the central curriculum served them for the aim to enhance the Druze identity, separated from the other history curricula for the Arab Palestinians. Despite the criticism from some Druze characters the new Druze educational system had been put in practice and Druze Heritage curriculum is considered, nowadays, one of the seven core subjects that Druze students should be examined for graduation of high schools (bagrut). Soad Abu Rukon, a Druze instructor and researcher, studied the contribution and the purpose of the Druze Heritage curriculum of the Ministry of Education for the Druze students to know their history, religion and community. She has concluded that the contents transmitted within Heritage lessons serve the goals of the Heritage curriculum despite the lack of students' interaction with some of the contents (Abu Rukon, 2011, pp. 104-109).

Recently there began to rise sounds of demands and organizations from high ranking educated people among the Arab Palestinian society in Israel, demanding for taking part of important decisions of them education. In March 2010 about 20 members of educated Arab held a meeting dealing in forming an "Arab Educational Council". The members took some important decisions:

- The Arab Educational Council is considered a functional framework of the collective right for the Arab Palestinians in Israel, with an independent administration for their educational affairs.

- The Council will spare no efforts for getting recognition in the Arab Education as national and cultural significance. The component of the organizational council includes 25 members.

- To take part in formulating educational strategies, including objectives, curricula and contents.

- To serve as effective body for making educational and cultural policies and decisions, and recommending alternatives, by presenting critical revisions (The Arab Educational Council, March 8, 2010).

By late October 2011, The Arab Educational Council announced ten points of the main objectives of the Arab education in Israel. Some of the important points stressed to enhance the belonging to the Palestinian Arab national identity with its culture and Arabic language, and its deep historical background. Moreover, the objectives emphasized on the historical and political rights of the Palestinian people with their historical narratives and collective memory, with taking into consideration the religious, societal and cultural pluralism among the Palestinian society (The Arab Educational Council, November 1, 2011). In January 2012 a conference had been held in Nazareth by the Arab Educational council under the title "The Arab Educational council: A 
collective Right and Educational Requirements". The participants discussed in their sessions two main topics: the objectives of the Arab education and the function of the Arab Educational Council under all the obstacles expected. (Qiblawi, January 22, 2012)

Despite all of changes and developments since 1948 until recent times, the question remains the same: Will the Israeli authorities accept and adopt those controversies and take into consideration the Arab Palestinian requirements? Lately it is clearly that the Israeli authorities, especially Ministry of Education try to forbade commemorations of important events related to the collective memory of the Palestinians, such as: the (Nakba), "Palestinian Disaster" in 1948 "land day" (Yawm al-Ard), "October events" (Intifada) and other important political events. Such commemorations are now about to become explicitly banned by the Ministry of Education. Such orientation will leave a negative impact on students by the time.

Palestinian history teachers can do little to correct this negative trend. They are limited by the state curriculum and textbooks and banned from turning aside from these texts. Ultimately Palestinian students have no choice but to memorize history as it is presented in the textbooks, in the light of the official curricula and policy, because they will take their final high school graduation exams (bagrut), in which the control is in the hand of Ministry of Education in preparing the questions and evaluating the students' answers.

\section{Conclusion}

Although changes and reforms had taken place in history curricula for Arab Palestinian students in Israel, it is noticeable that the Zionist historical narrative is imposed again on Palestinian students in history textbooks which ignore the history and culture of the Palestinian people. Main chapters connected to the history of the Palestinian people, has been erased in the late revised curriculum of 2007. On the other side, as Daniel Bar-Tal stated in his conclusions about history education for Jewish students, that one might add that it takes many years to rewrite school textbooks, and a few generations to change the societal beliefs about the stereotyping and de-legitimization of the Arabs (Bar-Tal, 2001).

As result of all changes mentioned above, people connected to teaching history or history curricula, Palestinian Arabs as Jews, are amazed about the mission and purpose of history teaching and education in Israeli schools. Did history aim to transmit to the students a specific version of the past as inheritance and collective memory? Or, is history considered as a basic stage in affording disciplinary qualifications to prepare students towards higher education and critical thinking about historical events in the past, and judge them for the future? But the question still troubling the Palestinians in Israel is the Jewish control on Arab schools, curricula and textbooks and the reliance of history education for Arab student on the high policy of Jewish decision designers (Abu Saad, 2011, pp. 109-111; Kabha, 2009, pp. 71-76).

\section{References}

Abu Asba, Kh. (2006). Education System in Israel: Contents, Streams and Methods of Action. Ram-Allah: Palestinian Center of Studies.

Abu Rukon, S. (2011). The Contribution of Heritage Teaching for Designing the Ethnic-Religious Identity among Druze Adolescents. Al-Nibras, 6, 104-117.

Abu Saad, I. (2006a). State Educational Policy and Curriculum: The Case of Palestinian Arabs in Israel. International Education Journal, 5, 709-720.

Abu Saad, I. (2006b). State-Cotrolled Education and Identity Formation among the Palestinian Arab Minority in Israel. American Behavioral Scientist, 49(8), 1058-1100. https://doi.org/10.1177/0002764205284720

Abu Saad, I. (2008). Present Absentees: The Arab School Curriculum in Israel as a Tool for De-educating Indigenous Palestinian. Holy Land Studies: A Multidisciplinary Journal, 7(1), 17-43. https://doi.org/10.3366/E147494750800005X

Abu Saad, I. (2011). Arab Education in Israel and the Policy of Control: The Case of Education in the Negev. Israel: Ben-Gurion University of the Negev Press.

Abu Saad, I., \& Mahamid, H. (2014). School Curriculum and the Development of Identity among Palestinian Youth in the System of Arab Education in Israel. Al-Nibras, 8, 48-83.

Al-Haj, M. (1994). Preparing Educational Curricula in Arab Educational System in Israel; Changes and Recommendations. Jerusalem.

Al-Haj, M. (1995). Education, Empowerment and Control: The Case of the Arabs in Israel. State University of New York, NY: Albany. 
Al-Haj, M. (2005, March). National Ethos, Multicultural Education, and the New History Textbooks in Israel. Curriculum Inquiry, 35(1), 47-71. https://doi.org/10.1111/j.1467-873X.2005.00315.x

Barak, O. (2004, May 23). The Palestinian Chapters disappear in the way to Classes. Retrieved from http://www.haaretz.co.il/news/health/1.968948

Barghouti, S. (2009, Autumn). Palestinian History and Identity in Israeli Schools. Retrieved from http://www.badil.org/en/al-majdal/item/1265

Bar-Tal, D. (2001, September). The Arab Image in Hebrew School Textbooks. Palestine-Israel Journal of Politics, Economics \& Culture, 8(2), 5.

Bar-Tal, D., \& Zoltak, S. (1989). Images of an Arab and Jewish-Arab Relations in School Readers. Megamot, 301-317.

Bronner, E. (1999, August 14). Israel's history textbooks replace myths with facts. The New York Times.

Firer, R. (2008). Virtual Peace Education. Journal of Peace Education, 5(2), 193-207. https://doi.org/10.1080/17400200802264479

Firer, R., \& Adwan S. (2004). The Israel-Palestinians conflict in history and civics textbooks of both nations. Hanover: Verlag Hansche.

Gelber, Y. (2009, October). History Teaching in Israel and in the World. Jerusalem: The Institute for Zionist Strategies.

Golan-Agnon, D. (2005). Inequality in Education and Discrimination against Palestinian Arab Students in Israel. In D. Champagne, \& Abu-Saad, I. (Eds.), Indigenous and Minority Education: International Perspectives on Empowerment (pp. 201-214). Beer Sheva: Negev Center for Regional Development, Ben-Gurion University of the Negev.

History Curriculum for High Arab Schools (10th-12th Grade). (1999) (Experimental edition). Jerusalem: The Ministry of Education, Culture and Sports, Education Administration, The Center for Educational Curricula.

History Curriculum for High Arab Schools (10th-12th Grade). (2007) (Revised edition). Jerusalem: The Ministry of Education, Culture and Sports, Education Administration, The Center for Educational Curricula.

Kabha, M. (2009). Reading in the First Curriculum for History Education in Arab Schools in Israel. Al-Nibras, 5, 71-76.

Khoury, J. (2011, September 5). Israel's textbooks in Arabic are Full of Mistakes, Study Finds. Retrieved from http://www.haaretz.com/print-edition/news/israel-s-textbooks-in-arabic-are-full-of-mistakes-study-finds-1.3 60617

Kimmerling, B. (2001). The Invention and Decline of Israeliness. Berkeley: University of California Press.

Mar'i, S. (1978). Arab Education in Israel. In Syriacus. New York: Syriacus University Press.

Mathias, Y. (2002). The crisis of the national paradigm history in Israel curriculum during the 1990s. International Textbook Research, 24(4), 427-443.

Mathias, Y. (2005). Curriculum between Politics and Science: The Case of History in Israel after the Six Day War. Political Crossroads, 12, 47-65. https://doi.org/10.7459/pc/12.1.04

Naveh, E., \& Yogev, E. (2002). Histories, towards dialogue with yesterday. Tel-Aviv: Bavel.

Peled-Elhanan, N. (2012). Palestine in Israeli School Books: Ideology and Propaganda in education. London: I. B. Tauris.

Podeh, E. (2002). The Arab-Israel conflict in Israeli history textbooks, 1948-2000. Westport, CT: Bergin \& Garvey.

Qiblawi, M. (2012, January 22). The Arab Educational council: A collective Right and Educational Requirements. Retrieved from http://www.bokra.net/Articles/1121094

Raz-Karkotzkin, A. (1997). Bi-nationalism is the Solution. News from Within, 7(9), 19-21.

The Arab Educational Council. (2010, January 1). A follow-up Committee on Arab Education-Israel. Retrieved from http://arab-education.org/?p=51/

The Arab Educational Council. (2010, March 8). The Arab Educational Council Held its First Meeting. Retrieved from http://arab-education.org/?p=202 
The Arab Educational Council. (2011, November 1st). A Document: Objectives of Education and Culture for the Arab Palestinian Minority in Israel. Retrieved from http://arab-education.org/?p=1287

Yogev, E. (2007). Promoting Understanding through Teaching History. In P. A. Bartolo, A. Mol Lous, \& T. Hofsass (Eds.), Responding to Student Diversity: Teacher Education and Classroom Practice (pp. 295-314). Qawra: Malta University.

Yogev, E. (2010). A Crossroads: History Textbooks and Curricula in Israel. Journal of Peace Education, 7(1), 1-14. https://doi.org/10.1080/17400200903370852

Zemer-Pronfman, E. (2011, April 26). For the First Time: Obligation in Teaching the Holocaust for Arab Community. Retrieved from http://www.nrg.co.il/online/1/ART2/235/122.html

Zonszein, M. (2011, May 25). Teaching Nakba in Israeli Schools: Tools or Weapons? Retrieved from http://972mag.com/author/mairavz/page/7/

\section{Note}

Note 1. After issuing the list of "The Hundred Concepts" serving the Jewish heritage, there had been strong criticism and responses against this act and its purpose from the Arab community in Israel. As an opposite act, a group of high ranking educated Arab Palestinians prepared and issued an opposite list of concepts serving the Palestinians heritage titled "Identity and Belonging: Concepts for Arab Students". (See the two opposite lists: Abu Saad, 2011, pp. 129-130, 134)

\section{Copyrights}

Copyright for this article is retained by the author(s), with first publication rights granted to the journal.

This is an open-access article distributed under the terms and conditions of the Creative Commons Attribution license (http://creativecommons.org/licenses/by/4.0/). 